\title{
The role of information management in project management success: Narratives from entrepreneurs \\ operating within the South African construction industry
}

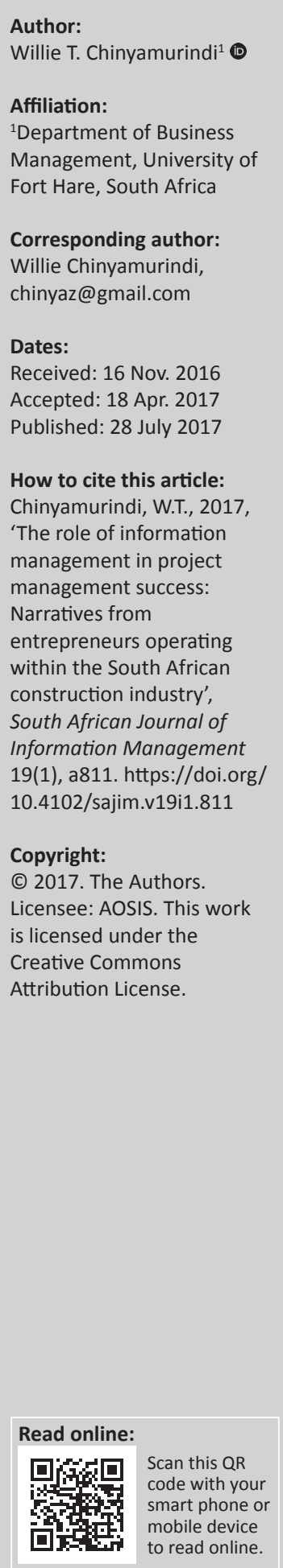

Background: The South African construction industry is noted to be one of the most popular industries heavily dependent on projects. Calls exist for research that ascertains not just how entrepreneurs act as project managers but also the evaluation of project success and the role information management plays in all this.

Objectives: The aim of this study was to understand the views and experiences of entrepreneurs in how: (1) project management success is conceptualised, and (2) the role that information management played to this within a South African construction industry space.

Method: The study adopts a qualitative research approach using semi-structured interviews to generate narratives and themes around how: (1) project management success is conceptualised, and (2) the role that information management played to this. A sample of 15 entrepreneurs working within the construction industry was used for this study.

Results: Based on the analysis of the narratives of the 15 entrepreneurs, project success was conceptualised mainly along three themes. Firstly, project success was about keeping the customer happy. Secondly, project success in the construction industry meant meeting the set targets, especially those of a financial nature. Finally, project success was about channelling internal synergies to realise external gains. Further, the 15 entrepreneurs espoused one main sub-theme around the role of information management to this conceptualisation of project success. This posits the role of information management to be a currency in effective decision-making.

Conclusion: The study concluded by focusing on the implications and recommendations based on the identified themes.

\section{Introduction}

To entrepreneurs and managers, projects potentially play an important role in either the success or failure of their business ventures. Some (e.g. Jansson \& Ljung 2013) have even argued for project activity as key in changing organisations. Thus, it becomes imperative not only to study projects as units of analysis but also to manage them, including stakeholder behaviour (Eskerod \& Huemann 2013), with the ultimate aim of project success and quests for sustainability (Jansson \& Ljung 2013). Further, calls exist for research that seeks to understand the link between project management and entrepreneurship as not only related concepts but also the complexity that characterise both (Hjorth, Holt \& Steyaert 2015). Given the existence of such complexity in the two processes (Sergi 2012), there is a need to understand such as a basis for suggesting interventions. However, the journey towards this is somewhat cumbersome. For instance, issues around managing project stakeholder expectations (Baroudi \& Rapp 2014), resource challenges (Chang et al. 2010, 2012), capability issues around projects (Crawford, Langston \& Barjachary 2012) and a consensus as to what ensures project success (Shenhar \& Dvir 2001) create empirical and practitioner dilemmas.

The management of projects is also argued to be similar and related to the practice of entrepreneurship, united by the performance action in the two disciplines (Lindgren \& Packendorff 2003). The active agent of this performative action is the entrepreneur who can also be argued to be a project leader in his or her own right (Flyvbjerg, Landman \& Schram 2012). The success of the entrepreneur in projects is influenced by the competition in the environment, and hence, the 
emphasis on information and its management is essential not just in innovation (Rossi, Vrontis \& Thrassou 2012; Jiang, Tao \& Santoro 2010) but also performance (De Faria \& Mendonca 2011).

As a result of all these, information management is argued to be a potential anchor for an organisation and its business activities (Sequeiraa et al. 2015). Hence, the need to pay attention to those factors that influence project success and also the success of entrepreneurial ventures in which projects can exist (Rossi, Vrontis \& Thrassou 2014). Further, the role of agents, such as those managing such entrepreneurial ventures, deserves attention. These agents can be argued to be relevant knowledge assets with the potential of affecting performance through their enactment of decisions (Del Giudice 2011).

This study locates itself within the view that information management, especially in small businesses, is a matter of concern, given the ramifications on both objective and subjective measures of project success (Soto-Acosta, Colomo-Palacious \& Popa 2014). Further, given that information management is argued to potentially play a major role in supporting innovation (Dougherty \& Dunne 2011), there is a need for a contextual understanding of project management and tenets such as project success (Carvalho, Fleury \& Lopes 2013).

Further, there is an acknowledgement from the literature that the success of an entrepreneurial venture (even through its projects) consists of quests for novelty and consistent practices (Blomquist, Hallgren, Nilsson \& Soderholm 2010; Drouin, Muller \& Sankaran 2013). Key to the success of all these is the value of information management as part of an innovation ecosystem (Adner \& Kapeer 2010) that relies on the management of knowledge (Soto-Acosta et al. 2014). Thus, a general research question is proposed: What is the role of information management within project management success from the lens of a sample of entrepreneurs operating within the South African construction industry?

The structure followed in this article is first to put this research into context. Secondly, the theoretical framework underlying this study is presented, leading to the justification of the research question. Thirdly, this is followed by the research design and methodology section. Finally, the results, discussion and a conclusion are presented.

\section{Putting this research into context}

One of the significant observations within the South African context is the growth of small, medium and micro enterprises (SMMEs) deemed to be a major driver of the economy (Chimucheka 2014). This realisation of the role of SMMEs has even led to the formation of a new government ministry dedicated to small business development. One of the primary goals of this ministry is to encourage the growth of small businesses, which subsequently has ramifications on the sustained livelihoods of communities. However, small business owners in their entrepreneurial efforts appear to face myriad challenges that impact not just their growth but also their survival (Chimucheka 2014). A key challenge concerns the management of projects that these entrepreneurs are engaged in within their business entities. The idea here is for quests for projects that are sustainable and hence, calls exist for empirical studies that investigate how this can be done (Gareis, Huemann \& Martinuzzi 2013; Silvius \& Schipper 2014). Further, the role of information management in achieving project success remains unclear. A process not made easy due to tools such as the Internet often results in information overload amongst decision-makers (Harris et al. 2015; Prytherch 2016). These challenges set the stage for calls in empirical work that explores not just the management of information management (Ajibade 2016; Waldman 2016) but also how this links within project management and specifically project success (Ghasabeh \& Chabok 2009).

\section{Theoretical background}

Although some possible theories exist to explain the idea of project success, this research adopts a multi-theory perspective in understanding the phenomena under study, rather than focusing on any one theory. Key to this are: (1) stakeholder theory (Freeman 1984), (2) resource-based views (RBV) (Wernerfelt 1984), and (3) the human capital theory (Connor \& Becker 1975).

Firstly, stakeholder theory can be an underlying theoretical lens to explain quests for project success. For instance, one important stakeholder and recipient of the end-product can be thought of as the customer. Thus, there is need to strive for customer satisfaction through products and services supplied to meet 'expectations' (Kruger, Ramphal \& Maritz 2013). In this quest, project success can be conceptualised as meeting the goal set for the entrepreneur by the client who is a customer with needs (Gareis et al. 2013). To this end, information becomes the currency that allows for this to happen (Erasmus, Strydom \& Rudansky-Kloppers 2013). There is thus need for quality information that is not only relevant but also on time as a basis for project success (Kruger et al. 2013). Therefore, value, as proposed by Freeman (1984), is in the perspective of the stakeholder and meeting any expectations they may have.

Conversely, another theoretical lens considered from the economics and strategic management disciplines is the RBV of the firm (Grant \& Jordan 2015). In essence, what makes a business entity successful also depends on its competitive advantage, uniqueness and ability (Wernerfelt 1984). Thus, an organisation's strategic possessions have the potential to determine project success. Information management within such a context has been found to be a potential determinant of success and the enactment of strategic decisions (Chinyamurindi 2016a). Further, the traditional barometers of project success such as cost, time and scope can be integrated with the internal resources to create value (Ali \& Kamaruzzaman 2010). Related to the RBV is the idea of dynamic capabilities that positions how an organisation organises and manages resources and processes to attain a 
goal (Wernerfelt 1984). Information management within such a process is crucial as there are quests for information that are not only grounded and supported by internal structures but also channelled resources towards success (Grant \& Jordan 2015).

Finally, given that the scope of this work is within the entrepreneurship field, the human capital theory is considered. Within this, the entrepreneur is argued to have knowledge and competencies that can affect their venture's effectiveness (Connor \& Becker 1975), thus positioning these entrepreneurial pursuits to be crucial for the success of activities and projects (Mueller, Volery \& Von Siemens 2012). Therefore, the success of projects can be argued to agentic and dependent on the entrepreneur with aspects such as their experience, knowledge, capability and drive being deemed fundamental to project success (Golini, Kalchschmidt \& Landoni 2015). Information management here is also considered to be essential as the entrepreneur is viewed to be an innovator who relies on and manages information to introduce new processes or products (Deakins \& Freel 2009).

\section{Determinants of project success and role of information management}

There appears to be no agreed measure of project success in general. Emuzei and Smallwood (2011) cite the challenge of quality as affecting the construction industry and hence, benchmarks of success should be based on improving quality. Patrick (2004) attributes project success to be consistent with the delivery of an end-product at the right time, costed properly and with emphasis on quality. Conversely, Ali and Kamaruzzaman (2010) narrow it to four issues as vital to project success: scope, cost, time and quality. Further, Ncwadi and Dangalazana (2006) advise that the success of the South African construction industry is dependent on addressing issues of productivity and quality problems that are significant challenges to the sector. Those engaged in such projects should meet the needs of the client (diverse as they may be) and their specifications (Battikha 2002; Yang et al. 2011).

Others take a different approach to measuring project success and concentrate more on the stakeholder. For instance, various scholars (e.g. Richard et al. 2009; Waddock \& Graves 1997) found success to be a situation when a stakeholder is satisfied. Information management within such a setting is viewed to be vital in not only organisational effectiveness but also meeting stakeholder needs (Santos \& Brito 2012). An essential aspect of information management here is information and communication technology systems (Prajogo \& Olhager 2012) as they can serve an information storage role and also one of analysis and evaluation (Uwizeyemungu \& Raymond 2009).

This study is located within the South African construction industry. Internationally, the construction industry is characterised by accelerated growth because of demand for housing as a basic necessity in life, especially in developing countries (Lepatner 2007). In South Africa, the construction industry is one of the fastest growing industries (Mofokeng 2012) although characterised by skilled workers (Human 2006). Notably, the construction industry is heavily dependent on projects as a modality of work (Mofokeng 2012).

In the construction industry, information management can be argued to be crucial, given three main reasons. Firstly, construction projects by nature are dependent on information because of the need for compliance, not just to stakeholder requirements but also to legislative frameworks (Emuzei \& Mhlwa 2015). This potentially places cadence on how issues around project success are arrived at and also how information (and the management of it) can be a useful currency. Secondly, the construction industry is competitively intense both locally and internationally (Emuzei \& Mhlwa 2015). Within such a context, there is a constant need to benchmark local performance to international standards as a way to solve challenges (Emuzei \& Smallwood 2011) and be competitive (Oakland \& Marosszeky 2005). Studies that investigate how project success happens (including the role of information management) in such competitively intense industries provide a useful springboard to constantly improve not just the financial performance but also sustainability issues in such industries.

Within the Information Systems (IS) and management disciplines, the construction industry has been the subject of empirical attention. Kelleger (2007) investigated the issues of information security within the construction industry using a sample of contractors. Another stream of work (e.g. Azzar \& Karam 2003; Ozumba \& Shakantu 2013) within the South African construction industry is around the adoption of information and communication technologies. This research differs from the identified studies within the IS and information management disciplines by seeking to understand how project management success is conceptualised, including the role of information management in arriving at this. This appears to be an empirical gap that has not yet been filled within the South African construction industry.

\section{Research methodology}

The study lends to the interpretivist paradigm of thinking (Creswell \& Clark 2011), with the aim of understanding the experiences of entrepreneurs (as individual actors) in their practice within the construction industry. Within this, the qualitative approach is adopted to collect information about the individual experience and deduce how these individuals infer meaning based on this experience (Thanh \& Thanh 2015). In essence, interpretivism as a philosophy and the qualitative approach were used as they provided deeper insights into the issues under investigation (Creswell \& Clark 2011). This is also an argument made (e.g. Konstantinou \& Müller 2016) for the need to use more interpretivist approaches both in the disciplines of project management and entrepreneurship, moving away from the dominant positivist and quantitative inclination usually adopted. 


\section{Data collection}

Given the proposed aims of this study, semi-structured interviews were used as a data collection tool. Such interviews allowed for the opportunity to follow a predetermined structure from which all participants had the opportunity to answer the same questions (Deschambault 2011). The duration of these interviews ranged from 45 to $60 \mathrm{~min}$ and were all conducted on the entrepreneurs' premises by appointment over an 8-month period. Ethical clearance was also applied for with the participating institution where the researcher was based. A total of 15 entrepreneurs all operating in the construction industry were interviewed (see Table 1). A purposive sampling approach was adopted (Ritchie et al. 2013) in which the researcher made a deliberate attempt to select participants based on set criteria (Yin 2014). According to Patton (1991), within purposive sampling, a researcher can use the snowball technique. In this study, the researcher relied on existing relationships that may exist between small businesses:

- operating within the Buffalo City Metropolitan Municipality

- operating for a period of 1-5 years since inception

- operating within the construction industry.

\section{Data analysis}

All interviews were recorded, and permission was sought from the participating entrepreneurs. As a standard rule, all entrepreneurs were informed that no identifying information was to be made available to them or their firms, hence the use of pseudonyms. Recordings were then transcribed verbatim within $24 \mathrm{~h}$ of the interviews being conducted. A qualitative analysis software, QSR International NVivo 9, was used for the purpose of data analysis and data management. Further, a means of data analysis adopted in previous studies was used (e.g. Chinyamurindi 2012, 2016a, 2016b) based on the three levels of meaning-making.

TABLE 1: Participant characteristics.

\begin{tabular}{|c|c|}
\hline Entrepreneur $(n=15)$ & Details of company \\
\hline Siphot, & $\begin{array}{l}\text { Project management firm that does costing for construction } \\
\text { projects. }\end{array}$ \\
\hline Gift $\uparrow, \$$ & $\begin{array}{l}\text { Construction company with a special focus on equipment } \\
\text { procurement. }\end{array}$ \\
\hline Zolat, : & $\begin{array}{l}\text { Construction company with an emphasis on engineering } \\
\text { consulting in the Eastern Cape Province of South Africa. }\end{array}$ \\
\hline Mary $\dagger, \S$ & Compliance and legal advice company. \\
\hline Sivuyilet, $\S$ & $\begin{array}{l}\text { Construction and renovation company with leading } \\
\text { government departments. }\end{array}$ \\
\hline Tshepot, & $\begin{array}{l}\text { Construction company with a special focus on equipment } \\
\text { procurement. }\end{array}$ \\
\hline Nwabisa†, § & $\begin{array}{l}\text { Project management firm that does costing for construction } \\
\text { projects. }\end{array}$ \\
\hline Anele†, & Construction engineering company. \\
\hline Thabs $\dagger, \S$ & Construction and infrastructure services company. \\
\hline Thulanit, & Construction engineering company. \\
\hline Zikhona†, § & Civil and construction services company. \\
\hline Kwanele†, \$ & $\begin{array}{l}\text { Project management firm that does costing for construction } \\
\text { projects. }\end{array}$ \\
\hline Jeremyt, & Construction engineering company. \\
\hline Vuyo $\dagger, \S$ & Construction company specialising in social housing projects. \\
\hline Babalwa†, § & $\begin{array}{l}\text { Independent construction consultant and owner of a } \\
\text { building evaluation company. }\end{array}$ \\
\hline
\end{tabular}

$\dagger$, Pseudonym; $\$$, Male participant; $\S$, Female participant.
Level 1 was helpful in developing a good understanding of the experiences (positive and negative) of entrepreneurs in the projects they engaged in. Further, the role of information management in such experiences was also analysed within this level through analysing each entrepreneur's story. To achieve this, transcripts were read and reread with the research, constantly referring to audio recordings as an information source. This process allowed for the identification of 'markers' in the stories (McCormack 2000:221) and answered questions about each interview, such as 'What kind of story is this?' (Thornhill, Clare \& May 2004:188).

Level 2 was achieved through classifying responses from participants into meaningful categories (Nachmias \& Nachmias 1996); the categories thus offered a basis to learn more not only about each story but also about the responses as a collective. The final stage consisted of the process of analysing the content extrapolated and generating a narrative through personal accounts, anecdotes and themes (McCormack 2000). The quotes had to be consistent across all the generated stories as prescribed by the literature (Rhodes 2000). Table 2 presents a summary of this data analysis process.

To ensure data credibility and integrity, some steps were taken as suggested from the literature (e.g. Rubin \& Rubin 2012). Firstly, a pilot study was conducted on a sample of three entrepreneurs (non-participating). The pilot study offered an opportunity for the researchers to familiarise themselves with nuances around conducting the research in preparation for the main study. Further, during the period of conducting the interviews, the researcher ensured that all interviews were not only recorded but also transcribed within $24 \mathrm{~h}$ of data collection. After this, participants were emailed copies of their interviews to verify whether they were a true account of what was stated during the interview. Finally, comprehensive notes as diary entries were also taken as part of the data collection process (Nicholl 2010).

Based on the narratives of the 15 entrepreneurs and the data analysis conducted, the following three main themes emerged:

- Project success as a quest for capitalising on internal and external pursuits.

- Information management role was centred on improving the decision-making capability of small businesses, and the projects entered into.

TABLE 2: Data analysis: Levels of meaning-making.

Level of meaning-making Description

\begin{tabular}{l}
\hline $11 \begin{array}{l}\text { Each interview is written as a brief vignette. After that, } \\
\text { each vignette is then developed into a longer narrative } \\
\text { about each participant. }\end{array}$ \\
$\begin{array}{l}\text { Narrative themes are conveyed by participants and their } \\
\text { experience of career development. After that, preliminary } \\
\text { themes are then compared across participants. } \\
\text { An analysis of the themes from cross-case comparison } \\
\text { begins and illustrating quotes and stories are used. }\end{array}$ \\
$\begin{array}{l}\text { Source: McCormack, C., 2000, 'From interview transcript to interpretative story: Part 1. } \\
\text { Viewing the transcript through multiple lenses', Field Methods 12(4): 282-297. https://doi. } \\
\text { org/10.1177/1525822X0001200402 }\end{array}$
\end{tabular}


- To achieve this information management role of decisionmaking (as in finding 2), the small business owners rely on a range of tools and techniques.

Each of these three main themes is presented next, including the codes leading to the themes, illustrating quotes and participant narratives.

\section{Findings}

\section{Theme 1: Project success as a quest for capitalising on internal and external pursuits}

Project success as per the framing of the participants was conceptualised, seeking a balance between internal and external pursuits. Mainly, internal efforts revolved around the channelling of internal synergies to realise external gains. For instance, this included making sure that processes within the small business run, so these can be realised in outputs such as firm performance. The external pursuits revolved around seeking to keep customers not only happy but also satisfied. Thus, project success in the construction industry as framed by participants of this study was driven by meeting set targets, especially those of a financial nature. Table 3 comprises quotes illustrating this first identified theme.

Linked to the quotes in Table 3 is the story shared by Babalwa (pseudonym) to support the findings as expressed in theme one. Babalwa had worked in the construction space for over 15 years with different reputable local and international firms. She stated:

'You see I now own my brand, but for 15 years I slaved for some local and international companies. One thing I have always enjoyed after a successful project, the sweet smell of success. Getting that call from a customer to thank my team and me. There is nothing so satisfying in our industry like that. Now in my practice, I still live by the mantra that the customer is king. Keep them happy, and you will smell success all the time in your projects.' [Babalwa, female, 34 years]

Another interesting participant story was from Mary (pseudonym) who ran a company that assisted players within the construction industry to adhere to compliance issues. About the findings expressed in Theme 1 of this research, the emphasis for Mary was meeting the set financial goals; Mary has set manuals on legal and compliance issues within the construction industry. In her interview, Mary shared:

'When I do my training and consultation. I always insist my clientele be aware that the law is meant to be there for a reason. Ultimately, I notice people view legal issues as stopping them from making money, but the reality [is] money made within the remit of the law is good. So one of the measures for success especially on construction projects revolves around making money make sense.' [Mary, female, 33 years]

Finally, a story supporting the first theme found in this research illustrates the quest for internal synergies for external gain as a basis for project success. Tshepo (pseudonym) described internal synergies as a form of 'skeleton' whose aim is not only to 'keep the body upright but also firm'. Tshepo, therefore, places cadence to getting the internal issues right first and the rest will follow after that (even external success). The second finding of this research centres on reporting the role of information management within project management and how this realises success.

\section{Theme 2: Information management role was centred on improving the decision-making capability of the small business, and the projects entered into}

The entrepreneurs participating in this research attributed information management to playing a role in assisting in the making of decisions for not only the project but also the business success. In arriving at this, the entrepreneurs participating in this study cited examples of how this happened. For instance, the management of information was deemed key when faced with issues around making decisions to complex problems that may be presented by an existing new client. The case of Zola seems to illustrate this:

'Within our industry how we manage information has a bearing on not just the decisions you make but also issues around success. Clients come to me requesting me to do costing for their construction projects. I must know the regulated costs as dictated by law. All this information must be kept not only safe but also within convenience so decisions can be made when clients come and see you.' [Zola, male, 45 years]

TABLE 3: Project success as a quest for capitalising on internal and external pursuits.

\begin{tabular}{|c|c|c|}
\hline Sub-theme & Main codes generated during analysis & Illustrating quotes \\
\hline $\begin{array}{l}\text { 1: Projects' success - } \\
\text { Keeping customers happy }\end{array}$ & $\begin{array}{l}\text { - Keeping clients satisfied } \\
\text { - Follow-up on clients' needs } \\
\text { - Linking needs of the client before and after }\end{array}$ & $\begin{array}{l}\text { 'The construction industry is really about deliverables, one key person to have in mind all the time } \\
\text { is the customer'. Vuyo } \\
\text { 'When I started my company, I realised I need to take the time to understand my customers; they } \\
\text { determine my success in the end'. Kwanele } \\
\text { 'Project success can never be separated from our clientele's needs. If you can deliver at such a } \\
\text { level, realise the benefits'. Zikhona }\end{array}$ \\
\hline $\begin{array}{l}\text { 2: Projects' success - } \\
\text { Meeting financial targets }\end{array}$ & $\begin{array}{l}\text { - Financial controls } \\
\text { - Fiscal discipline } \\
\text { - Budget monitoring }\end{array}$ & $\begin{array}{l}\text { 'This for me is a difficult thing; I must stay within the budget all the time, but sometimes it's not } \\
\text { always easy'. Jeremy } \\
\text { 'I just can't blow money on none essentials. Any wasteful expenditure will reflect negatively not } \\
\text { just on me but also the team'. Thabs } \\
\text { 'You know they say more money more problems. I choose to rethink all this, more money yes } \\
\text { please, else I must stay within the budget. That's the target, a difficult moving target sometimes'. } \\
\text { Nwabisa }\end{array}$ \\
\hline $\begin{array}{l}\text { 3: Projects' success - } \\
\text { Channelling internal } \\
\text { synergies to realise } \\
\text { external gains }\end{array}$ & $\begin{array}{l}\text { - Investment on machines and resources } \\
\text { - Effective human resource management } \\
\text { - Making sure internal processes are working } \\
\text { - Information gathering and sharing }\end{array}$ & $\begin{array}{l}\text { 'I am doing well because I think I can put the right people in my company to do the right things } \\
\text { outside. My best workers for the toughest job. The issue is knowing what these guys can do and } \\
\text { then place them outside based on their abilities'. Zola } \\
\text { 'We realised we needed new digging equipment and decided to invest in this. In the end, what we } \\
\text { have internally gives us money. There is no price one can put on the lack of investment especially } \\
\text { on machinery in our industry'. Gift }\end{array}$ \\
\hline
\end{tabular}


Another utility function of information management in assisting decision-making was to aid the filling in of tender documents and applying for bids. All participants in this study cited being on the lookout for ways to improving their business function through applying for bids. Further, given laws such as Broad-Based Black Economic Empowerment (BBBEE), the participating entrepreneurs cited benefiting from this corrective instrument of law, given the history of the country. One participant, Jeremy, cited his experiences of applying for bids and submitting tender documents and the value of information management in this.

'Every Friday we check The Daily Dispatch newspaper to make decisions on the advertised bids and tenders we can or cannot apply for. I guess as I tell my team all the time we need an effective and efficient digital archiving system that allows us to access files that improve our chances of getting tenders or bids.' [Jeremy, male, 52 years]

Figure 1 comprises quotes illustrating the second identified theme.

Participants in the study also cited the value of tools and techniques that help them in improving their information management role (as identified in finding 2), and these form the next and final finding of this study.

\section{Theme 3: Reliance on tools and techniques to assist information management role for project success}

The final theme of this study reports on the range of tools and techniques that assists the entrepreneurs in the construction management for project success. Figure 2 reports on the most popular project information management software used by the entrepreneurs in a year cycle (2016). It would appear that the usage of tools and techniques, including project information management software, is justified for one main reason and as found in the themes: to use information management as a currency for effective decision-making.

\section{Ethical consideration}

Ethical clearance was applied for with the participating institution where the researcher was based.

\section{Discussion}

The aim of this study was to qualitatively explore the role of information management in the project management success, based on the narratives of a sample of entrepreneurs operating within the South African construction industry. Based on the narratives of the 15 entrepreneurs interviewed in this study, the following three main themes emerged:

- Project success as a quest for capitalising on internal and external pursuits.

- Information management role was centred on improving the decision-making capability of the small business, and the projects entered into.

- To achieve this information management role of decisionmaking (as in finding 2), the small business owners rely on a range of tools and techniques.

With regards to the extant literature, this study through its findings heightens the focus and attention of the value of information management within entrepreneurial projects (Turner \& Müller 2003). Further, the study places focus as previous studies have done on the entrepreneur as an agent, in how small businesses can perform for project success (Achman 2011). One way this agentic power happens (as illustrated in this study) is through the decisions made by the entrepreneur (Eskerod \& Huemann 2013). Uniquely, the way this happens as illustrated in this study is through the management of information. Such efforts by entrepreneurs in this context are linked to not only the financial performance but also the sustainability of the entrepreneurial venture (Silvius \& Schipper 2014). In this study, as also found in previous studies, keeping customers happy while also seeking to perform better in a competitive environment is fundamental for project success (Baroudi \& Rapp 2014). In essence, through the first finding, what happens within the

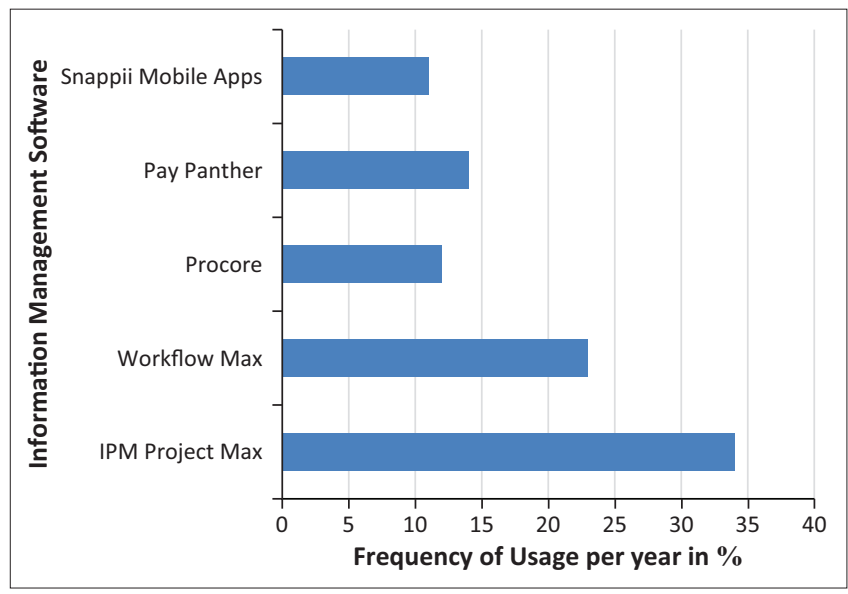

FIGURE 2: Project information management tools, techniques and software used.

\begin{tabular}{|l|l|}
\hline Main codes generated during analysis & Illustrating quotes \\
\hline $\begin{array}{l}\text { Basis for planning } \\
\text { - Infed for costing meetings } \\
\text { - Information decides next move } \\
\text { - Information to decide what not to do }\end{array}$ & $\begin{array}{l}\text { 'We work frantically to make sure we have information, not just any information } \\
\text { but reliable information. We are as a brand the information we have.'Sipho } \\
\text { 'Clients know us for the decisions we make, and these are based on good, sound } \\
\text { and financially tested scenarios.'Anele } \\
\text { 'Without information management software like Procore, our document audit } \\
\text { trail would be a mess. I don't care how expensive the software is. We needed to } \\
\text { make good decisions. In the end, this gives us success.'Zola }\end{array}$ \\
\hline
\end{tabular}

FIGURE 1: Role of information management in project success. 
small business can be a useful precursor to performance outcomes (Crawford et al. 2012).

The study also positions the disciplines of project management and entrepreneurship to be related. In this work, entrepreneurship activities could be framed as projects that position entrepreneurs to be project managers in their own right (Flyvbjerg et al. 2012). Information management can be thought to be a capability that allows the effective functioning of entrepreneurs as project managers. All these, as illustrated in this study, happen in a context driven by hypercompetition (Jiang et al. 2010). Finally, the study gives value to information management as a key anchor to an organisation (Sequeiraa et al. 2015). Notably, information management in project management, especially project management success, is a useful portal to have when making strategic decisions. This study has thus answered calls for empirical work that investigates not just project success but also the success of entrepreneurial ventures in which projects can exist (Rossi et al. 2014). The setting for all these was the construction industry using a sample of entrepreneurs in this industry. The study has contributions that have ramifications for theory, practice and policy. Firstly, calls have been made for more studies that adopt a qualitative focus, especially within the disciplines of project management and entrepreneurship (e.g. Konstantinou \& Müller 2016; Thanh \& Thanh 2015). This study contributes to the theoretical body of knowledge by not only illustrating the value of the qualitative paradigm but also showing the value of information management within entrepreneurial projects within the construction industry. Secondly, the study and its findings have implications for how practitioners (in this case, entrepreneurs) work within their fields. Practitioners about to enter the construction space, given its popularity in South Africa, can draw a lesson on how to thrive in such a competitive yet lucrative industry. Much can then be done to assist entrepreneurs to improve on how they manage information for the purpose of decision-making. This study heightens focus on improving internal organisational capabilities as they also assist in the use of information for decision-making. A starting premise can be through a personal commitment by the entrepreneurial owners of small businesses to realise that although they may be small, their expansion and growth can be dependent on improving such issues as internal synergies and how information is managed. Finally, policy-makers working in the space of entrepreneurship development can benefit from the findings of this work. Policy-makers cannot only have a deeper understanding of issues that affect entrepreneurs (given their contribution to the economy) but also infuse interventions to assist entrepreneurs.

\section{Limitations}

Some limitations exist within this work. Firstly, the study and its findings are in no way generalisable to the entire population of entrepreneurs operating within the construction space in South Africa. Related to this, the sample size used is only of 15 participants and thus, caution should be taken when interpreting the findings. Notably, this work sought to just explore a phenomenon (the conceptualisation of project success in the construction industry and the role of information management). Secondly, even amongst the entrepreneurs used for this study, although all operate in the construction industry, their roles and scope of operation are different. Hence, the diverse viewpoints shared can be a limitation, and an appeal is made to view the findings cautiously. Despite these limitations, the study helped understand the potential linkages that exist between the disciplines of entrepreneurship and project management. In essence, the role of information management in these two disciplines has been argued for as crucial in the making of strategic decisions.

Future research can use a larger sample base that consists of those entrepreneurs who work within the same scope of activity within the construction industry. A triangulation approach can help improve the veracity of this research through using both the quantitative and qualitative research approaches. Because of the way this study was framed, project success appeared to the area of interest. However, future research can investigate experiences of entrepreneurs who may have failed in their projects and draw lessons learnt from this experience. Further, it would be interesting to ascertain the role and approaches adopted even though the projects may have failed. The experiences of project success and failure could be a basis for an interesting comparison. Finally, research could improve this work by comparing the issues addressed between the construction industry and any other industry. Such a comparative approach can be useful to gauge similarities and differences with the view to better understand issues around information management within projects. Further, the study could also benefit from future research in other countries or regions. Again, this can be a useful basis for comparison.

\section{Conclusion}

The management of information within entrepreneurial projects has been argued to be an important capability that can determine the success of small business. In achieving this, there is need to continue building on internal and external aspects to the small business as support buffers not just for project success but also for the success of the small business. Within the construction industry as illustrated in this study, this can be possible. However, emphasis should be on making sure that there is a commitment to solving the issues before the entrepreneur.

\section{Acknowledgements Competing interests}

The author declares that he has no financial or personal relationship(s) that may have inappropriately influenced him in writing this article.

\section{References}

Achman, R., 2011, 'Stakeholder's perspectives on sustainable project management', Delft: Unpublished master's thesis, Delft University of Technology.

Adner, R. \& Kapoor, R., 2010, 'Value creation in innovation ecosystems: How the structure of technological interdependence affects firm performance in new technology generations', Strategic Management Journal 31(3), 306-333. https:// doi.org/10.1002/smj.821 
Ajibade, P., 2016, 'Validating information sensing in a South African University as an impetus to improved information management practice and performances', Journal of Social Sciences 48(3), 225-238.

Ali, A.S. \& Kamaruzzaman, S.N., 2010, 'Cost performance for building construction projects in Klang Valley', Journal of Building Performance 1(1), 113-116.

Azzar, A. \& Karam, A.H., 2003, 'A comparative study: With insight into the use of IT in local architectural practices', in R. Amor (ed.), Proceeding CIB-W78 International Conference on Information Technology for Construction, University of Auckland, Auckland, New Zealand, April 23-25, pp. 8-14.

Baroudi, B. \& Rapp, R.R., 2014, 'Stakeholder management in disaster restoration projects', International Journal of Disaster Resilience in the Built Environment 5(2), 182-193. https://doi.org/10.1108/IJDRBE-07-2012-0021

Battikha, M.G., 2002, 'Quality management practice in highway construction', International Journal of Quality \& Reliability Management 20(5), 7-9.

Blomquist, T., Hällgren, M., Nilsson, A. \& Söderholm, A., 2010, 'Project-as-practice: In search of project management research that matters', Project Management Journal 41, 5-16. https://doi.org/10.1002/pmj.20141

Carvalho, M.M., Fleury, A. \& Lopes, A.P., 2013, 'An overview of the literature on technology road mapping (TRM): Contributions and trends', Technological Forecast and Social Change 80, 1418-1437. https://doi.org/10.1016/j.techfore. Forecast and

Chang, Y., Wilkinson, S., Potangaroa, R. \& Seville, E., 2010, 'Resourcing challenges for post-disaster housing reconstruction: A comparative analysis', Building Research and Information 38(3), 247-264. https://doi.org/10.1080/09613211003693945

Chang, Y., Wilkinson, S., Seville, E. \& Potangaroa, R., 2012, 'Changes in resource need for post-disaster reconstruction: A longitudinal study in China', Building
Research and Information 40(3), 327-336. https://doi.org/10.1080/09613218. 2012.684867

Chimucheka, T., 2014, 'Entrepreneurship education in South Africa', Mediterranean Journal of Social Sciences 5(2), 403-416. https://doi.org/10.5901/mjss.2014. v5n2p403

Chinyamurindi, W.T., 2012, 'Stories of career change amongst distance learners in South Africa', South African Journal of Human Resource Management 10(2), 1-11.

Chinyamurindi, W.T., 2016a, 'Using narrative analysis to understand factors influencing career choice amongst a sample of distance learning students in South Africa' South African Journal of Psychology 46(3), 390-400. https://doi.org/10.1177/ 0081246315623662

Chinyamurindi, W.T., 2016b, 'A narrative investigation into the meaning and experience of career success: Perspectives from women participants', South African Journal of Human Resource Management 14(1), 1-11. https://doi.org/10.4102/sajhrm. v14i1.659

Connor, P.E. \& Becker, B.W., 1975, 'Values and the organisation: Suggestions for research', Academy of Management Journal 18, 550-561. https://doi.org/10.2307/255684

Crawford, L., Langston, C. \& Bajracharya, B., 2012, 'Building capability for disaster resilience', paper presented at the 28th Annual Conference of Association of Researchers in Construction Management (ARCOM), Edinburgh, Scotland, 3-5 September, 2012.

Creswell, J.W. \& Clark, V.L., 2011, Designing and conducting mixed methods research, 2nd edn., Sage, London.

De Faria, P. \& Mendonça, J., 2011, 'Innovation strategy by firms: Do innovative firms grow more?', International Journal of Entrepreneurship and Small Business 12(2), 173-184. https://doi.org/10.1504/IJESB.2011.038535

Deakins, D. \& Freel, M., 2009, Entrepreneurship and small firms, 5th edn., McGraw Hill, London.

Del Giudice, M., 2011, 'Knowledge management and family business', in M. Del Giudice, M.R. Della Peruta \& E.G. Carayannis (eds.), Knowledge and the family business (pp. 11-46), Springer, New York.

Deschambault, R., 2011, "From "analystci nuisance" to interactional resource: Reviewing small stories within interviews in mixed methods', Journal of Pragmatics viewing small stories within interviews in mixed methods', Journal

Dougherty, D. \& Dunne, D.D., 2011, 'Organizing ecologies of complex innovation', Organization Science 22(5), 1214-1223. https://doi.org/10.1287/orsc.1100.0605

Drouin, N., Müller, R. \& Sankaran, S., 2013, Novel approaches to organizational project management research, Copenhagen Business School Press, Copenhagen.

Emuzei, F.A. \& Mhlwa, C., 2015, 'Managing quality on construction sites in South Africa: An Eastern Cape study', Journal of Construction Project Management and Innovation 5(2), 1224-1237.

Emuzei, F.A. \& Smallwood, J.J., 2011, 'Construction industry development: A South African perspective', in Proceedings of the 2011 CIB-W107-Construction in Developing Countries International Conference, November 1-3, Hanoi, Vietnam, pp. 109-113.

Erasmus, B.J., Strydom, J.W. \& Rudansky-Kloppers, S., 2013, Introduction to business management, Oxford University Press, Cape Town.

Eskerod, P. \& Huemann, M., 2013, 'Sustainable development and project stakeholder management: What standards say', International Journal of Management Project and Business 6(1), 36-50. https://doi.org/10.1108/17538371311291017

Flyvbjerg, B., Landman, T. \& Schram, S. (eds.), 2012, Real social science: Applied phronesis, Cambridge University Press, Cambridge, UK.

Freeman, R.E., 1984, Strategic management: A stakeholders approach, Pitman, Boston.

Gareis, R., Huemann, M. \& Martinuzzi, A., 2013, Project management \& sustainable development principles, Project Management Institute, New-town Square, PA.
Ghasabeh, M.S. \& Chabok, K.K., 2009, 'Generic project success and project management success criteria and factors: Literature review and survey', WSEAS Transactions on Business and Economics 6(8), 456-468.

Golini, R., Kalchschmidt, M. \& Landoni, P., 2015, 'Adoption of project management practices: The impact on international development projects of non-governmenta organizations', International Journal of Project Management 33, 650-663. https:// doi.org/10.1016/j.ijproman.2014.09.006

Grant, R.M. \& Jordan, J.J., 2015, Foundations of strategy, 2nd edn., Wiley Press, United Kingdom.

Harris, K.J., Harris, R.B., Carlson, J.R. \& Carlson, D.S., 2015, 'Resource loss from technology overload and its impact on work-family conflict: Can leaders help?', Computers in Human Behavior 50, 411-417. https://doi.org/10.1016/j.chb.2015.04.023

Hjorth, D., Holt, R. \& Steyaert, C., 2015, 'Entrepreneurship and process studies' International Small Business Journal 33(6), 599-611. https://doi.org/10.1177/ 0266242615583566

Human, D., 2006, 'Implementation of affirmative action and Black Economic Empowerment (BEE) in the construction industry', viewed 4 March 2016, from http://www.icoste.org/ASAQS_Human.pdf

Jansson, T. \& Ljung, L., 2013, 'Strategic project archetypes for effective project steering', Procedia-Social and Behavioral Sciences 74, 112-122. https://doi.org/ 10.1016/j.sbspro.2013.03.042

Jiang R.J., Tao, Q.T \& Santoro, M.D., 2010, 'Alliance portfolio diversity and firm performance', Strategic Management Journal 31, 1136-1144. https://doi.org/ $10.1002 / \mathrm{smj} .869$

Kelleger, K., 2007, 'Construction equipment theft a "low risk" gamble', Journal of Commerce, viewed 23 February 2016, from http://www.journalofcommerce. com/article/id23659

Konstantinou, E. \& Müller, R., 2016, 'The role of philosophy in project management', Project Management Journal 47(2), 3-5.

Kruger, D., Ramphal, R. \& Maritz, M., 2013, Operations management, 3rd edn., Oxford University Press, Cape Town, Southern Africa.

Lepatner, B., 2007, Broken buildings, busted budgets: How to fix America's trillion dollar construction industry, University of Chicago, New York.

Lindgren, M. \& Packendorff, M., 2003, 'A project-based view of entrepreneurship: Towards action-orientation, seriality and collectivity', in C. Steyaert \& D. Hjorth (eds.), New movements in entrepreneurship, Edward Elgar, Cheltenham, pp. 86-102.

McCormack, C., 2000, 'From interview transcript to interpretative story: Part 1. Viewing the transcript through multiple lenses', Field Methods 12(4): 282-297. https://doi.org/10.1177/1525822X0001200402

Mofokeng, T.G., 2012, 'Assessment of the causes of failure among small and medium sized construction companies in the Free State Province', Doctoral dissertation, University of Johannesburg, South Africa.

Mueller, S., Volery, T. \& Von Siemens, B., 2012, 'What do entrepreneurs actually do? An observational study of entrepreneurs' everyday behavior in the start-up and An observational study of entrepreneurs' everyday behavior in the start-up and
growth stages', Entrepreneurship Theory and Practice 36(5): 995-1017. https:// growth stages', Entrepreneurship Theory and
doi.org/10.1111/j.1540-6520.2012.00538.x

Nachmias, F.C. \& Nachmias, D., 1996, Research methods in the social sciences, 5th edn, Worth Publishers, New York.

Ncwadi, M.R. \& Dangalazana, T., 2006, 'An analysis of the challenges facing emerging contractors in the Nelson Mandela Metropolis', Africa Insight 36(3/4), 189-194.

Nicholl, H., 2010, 'Diaries as a method of data collection in research', Paediatric Nursing 22(7), 16-20. https://doi.org/10.7748/paed.22.7.16.s25

Oakland, J.J. \& Marosszeky, M., 2005, Total quality in construction supply chain, 1st edn., Routledge, New York.

Ozumba, A.O.U. \& Shakantu, W.M.W., 2013, 'Investigating barriers to ICT adoption in site management: A pilot study in South Africa', in Proceedings, RICS COBRA 2013 Conference, New Delhi, India, Royal Institute of Chartered Surveyors, September 11-13, 2013, pp. 7-18.

Patrick, C., 2004, Construction project planning and scheduling, 1st edn., Pearson Education, Upper Saddle River, NJ.

Patton, M.Q., 1991, 'Towards utility in reviews of multivocal literatures', Review of Educational Research 61(3), 287-292. https://doi.org/10.3102/00346543061003287

Prajogo, D. \& Olhager, J., 2012, 'Supply chain integration and performance: The effects of long-term relationships, information technology and sharing, and logistics integration', International Journal of Production Economics 135(1), 514-522. https://doi.org/10.1016/j.ijpe.2011.09.001

Prytherch, R., 2016, Harrod's librarians' glossary and reference book: A directory of over 10,200 terms, organizations, projects and acronyms in the areas of over 10,200 terms, organizations, projects and acronyms in the areas of
information management, library science, publishing and archive management, information managem
Routledge, New York.

Rhodes, H., 2000, Mid-life career change to home-based self-employment in a group of women, Unpublished master's dissertation, Simon Fraser University, British Columbia, Canada.

Richard, P.J., Devinney, T.M., Yip, G.S. \& Johnson, G., 2009, 'Measuring organisational performance: Towards methodological best practice', Journal of Management 35(3), 718-804. https://doi.org/10.1177/0149206308330560

Ritchie, J., Lewis, J., Nicholls, C.M. \& Ormston, R., 2013, Qualitative research practice: A guide for social science students \& researcher, Sage Publications, Thousand A guide for.
Oaks, CA.

Rossi, M., Vrontis, D. \& Thrassou, A., 2012, 'Wine business in a changing competitive environment-strategic and financial choices of Campania wine firms', International Journal of Business and Globalisation 8(1), 112-130. https://doi.org/10.1504/ IJBG.2012.043975

Rossi, M., Vrontis, D. \& Thrassou, A., 2014, 'Agro business in a changing competitive environment-Campania firms' strategic, marketing and financial choices', World Review of Entrepreneurship, Management and Sustainable Development 10(2-3), 312-333. 
Rubin, H.J. \& Rubin, I.S., 2012, Qualitative interviewing: The art of hearing data, 3rd edn., Sage, Thousand Oaks, CA.

Santos, J.B. \& Brito, L.A.L., 2012, 'Toward a subjective measurement model for firm performance', BAR, Rio de Janeiro 9(6), 95-117.

Sequeiraa, F.R., Frantzb, R.Z., Yevseyevac, I., Emmerichd, M.T.M. \& Basto-Fernandese, V., 2015, 'An EAl based integration solution for science and research outcomes information management', Procedia Computer Science 64, 894-901. https://doi. org/10.1016/j.procs.2015.08.604

Sergi, V., 2012, 'Bounded becoming: Insights from understanding projects in situation', International Journal of Managing Projects in Business 5(3), 345-363. https://doi. org/10.1108/17538371211235263

Shenhar, A.J., Dvir, D., Levy, O. \& Maltz, A.C., 2001, 'Project success: A multidimensional strategic concept', Long Range Planning 34, 699-725. https://doi.org/10.1016/ S0024-6301(01)00097-8

Silvius, A.J.G. \& Schipper, R., 2014, 'Sustainability in project management: A literature review and impact analyses', Social Business 4(1), 63-96. https://doi.org/10.1362/ 204440814 X13948909253866

Soto-Acosta, P., Colomo-Palacios, R. \& Popa, S., 2014, 'Web knowledge sharing and its effect on innovation: An empirical investigation in SMEs. Knowledge management', Research \& Practice 12(1), 103-113. https://doi.org/10.1057/kmrp.2013.31

Thanh, C.N. \& Thanh, T.T., 2015, 'The interconnection between interpretivist paradigm and qualitative methods in education', American Journal of Educational Science $1(2), 27-27$.
Thornhill, H., Clare, L. \& May, R., 2004, 'Escape, enlightenment and endurance: Narratives of recovery from psychosis', Anthropology and Medicine 11, 181-199. https://doi.org/10.1080/13648470410001678677

Turner, J.R. \& Müller, R., 2003, 'On the nature of the project as a temporary organization', International Journal of Project Management 21(1), 1-8. https:// doi.org/10.1016/S0263-7863(02)00020-0

Uwizeyemungu, S. \& Raymond, L., 2009, 'Exploring an alternative method of evaluating the effects of ERP: A multiple case study', Journal of Information Technology 24, 251-268. https://doi.org/10.1057/jit.2008.20

Waddock, S.A. \& Graves, S.B., 1997, 'Quality of management and quality of stakeholder relations', Business and Society 36(3), 250-279. https://doi.org/ 10.1177/000765039703600303

Waldman, W., 2016, 'The applications of information technology to the human services: Challenges and opportunities', Human Service Organizations: Management, Leadership and Governance 40(5), 441-443. https://doi.org/10.10 80/23303131.2016.1165049

Wernerfelt, B., 1984, 'A resource-based view of the firm', Strategic Management Journal 5(2), 171-180. https://doi.org/10.1002/smj.4250050207

Yang, J., Shen, Q., Ho, M., Drew, D. \& Xue, X., 2011, 'Stakeholder management in construction: An empirical study to address research gaps in previous studies',
International Journal of Civil Engineering and Management 15(4), 337-340. https://doi.org/10.3846/1392-3730.2009.15.337-348

Yin, R.K., 2014, Case study research design and methods, 5th edn., Sage Publications, Thousand Oaks, CA. 